\title{
Bestelako eskola eredu bat posible da: Bizilore, eskola komunitate berri baten lehen urratsak
}

\author{
Ane Aranburu \\ Haur Hezkuntzan graduatua \\ Hezkuntza eta Kirol Fakultatea (UPV/EHU) \\ Alaitz Tresserras \\ Didaktika eta Eskola Antolakuntza \\ Hezkuntza eta Kirol Fakultatea (UPV/EHU) \\ alaitz.tresserras@ehu.eus \\ Rakel Gamito \\ Didaktika eta Eskola Antolakuntza \\ Hezkuntza eta Kirol Fakultatea (UPV/EHU) \\ rakel.gamito@ehu.eus \\ Ainhoa Gómez \\ Musika, Plastika eta Gorputz Adierazpidearen Didaktika \\ Hezkuntza eta Kirol Fakultatea (UPV/EHU) \\ ainhoa.gomez@ehu.eus
}

DOI: http://dx.doi.org/10.1387/tantak.18122

GAKO-HITZAK: haurraren ongizatea, eskola aktiboa, hezkuntza-etnografia, dokumentazioa, Haur Hezkuntza.

\section{SARRERA}

Gaur egun gizarteak eta oro har munduak bizi dituen arazo larrien aurrean, pertsonen arteko erlazioak beste modu batera eraikitzeko bideak jorratzen dituzten ekimenak sortzen ari dira, Rebeca Wild (2007) pedagogoak aipatzen duen bezala. Egitura eta harreman mota berri horietan ez da inposatzen indartsuenaren nagusitasuna ahulenaren aurrean, ezta «jakintsuarena» «ez-jakinaren» gainean, edota «duenaren» «ez duenaren»au- 
rrean. Baina bide berri hori hartzeak eta orain arteko ikuspegia aldatzeak pertsona heldua erronka berrien aurrean jartzen du. Eta prest al gaude heldu bezala gure jokabideak errebisatzeko? Ohitura eta erreakzio inkontzienteak ezbaian jartzeko? Ba al dago interesik haurren garapen prozesuek eta helduarenak dituzten erlazioaz jabetzeko?

Haurrak interes ekonomikoei jarraitzen dien gizarte batera egokitu beharrean, pertsona bakoitzak bere garapenerako duen «barne-programa» errespetatzeari lehentasuna eman beharko genioke, garapen-etapa bakoitzerako giro egokiak prestatuz eta elkarrekintza-rolak aldatuz (Wild, 2007). Alegia, ikasleen ekintzak planifikatu eta definitu beharrean, haurrak sortzen dituen elkarrekintzetan babesa eskaini eta elkarlanean aritu beharko luke.

Azken urteotan hezkuntza munduan zenbait aldaketa ematen ari badira ere, zoritxarrez sistemak bere horretan dirau. Horregatik, ikerlan honetan eskola eredu berri baten filosofia eta hura gauzatzeko funtsezko elementu metodologikoak ezagutu nahi izan dira. Horretarako, hezkuntza-etnografia bat burutu da, Bizilore Azpeitiko (Gipuzkoa) eskola aktibo berriaren ildo teoriko-praktikoetan sakontzeko. Emaitzen atalean, berriz, iturri eta tresna desberdinen triangelukatzetik lortutako informazioa aurkeztu eta oinarri teorikoak ahaztu gabe interpretatu da. Amaitzeko, teoria eta praktikaren arteko eztabaidaren bitartez, eskola ulertzeko modu berri honek haurrari ekar diezazkion onurak identifikatu dira.

\subsection{Ikaslearengan oinarritutako eskola}

Tradiziozko hezkuntza, gehienbat, zenbait arau eta balio transmititzeaz arduratu dela esan daiteke, ikasleek jarrerak imitatu eta jakintza metatu dezaten ahaleginduz?. Baina hezkuntzak aurrera egin du eta, pixkanaka, bilakaera horretan, arreta ikaslearengan jarri du. Gero eta gehiago dira eskola eredu tradizionaletik urrun kokatzen diren zentroak eta eskola komunitateak.

UNESCOren arabera (2004), hezkuntzak, testuinguru guztietan, ikaslearengan oinarritutako ikaskuntza metodoak erabili behar ditu. Ikaslearengan zentratutako ikaskuntza markoetan, ikasleek izan behar dute arazoak identifikatzeko aukera, hala nola informazioa bildu eta aztertzeko, ondorioak ateratzeko eta emaitzak helarazteko aukera. Azken batean, ikasleak hezkuntzaren protagonista izan behar du.

Ikaslearengan oinarritutako hezkuntzak, edo hezkuntza ez zuzentzaileak, pertsonak hazi eta garatzeko duen funtzio aktiboa defendatzen du. Zentzu horretan, Rogers-en arabera (in Casanova, 1989), erronkak zuzendu gabeko espazio bat egokitzea izan beharko luke, epaiketetatik, balorazioetatik eta interpretazioetatik urrun dagoena, eta norbere hazkuntza prozesu bakar eta pertsonalean aske izatea ahalbidetzen duena, konparazioetatik libre.

Hezkuntza ez zuzentzailean, haurraren ekintza jakintza guztiaren oinarria da eta jarduera autonomoak eskaintzen duen gozamena, haurren he- 
ziketan oso kontuan hartu beharreko elementua. Horregatik, Loczy institutuan esaterako, oso txikitatik eskaintzen zaizkio haurrari bere jolas espontaneoaz gozatzeko erremintak, beti norberaren iniziatibatik sortuak. Haurrari mugitzeko askatasuna eskaintzen zaio eta helduaren jarrera eskuhartzailea ekiditen da, azken hori delako haurra pasibo bilakatzen duena (Pikler, 1984).

Badira erlazio hori beste era batera ulertzen dutenak ere bai. Italiako Reggio Emilia eskoletan, esaterako, erlazioari berari eman zaio garrantzia - ezagutza soiletik harago-, norbanakoaren esperientziari, askatasunaren eta arduren arteko ekintzari. Reggio Emilia pedagogian irakaspenaren aurrean ikasketarako aukera desberdinak sortzea balioetsi da (Hoyuelos, 2004).

\subsection{Eskola aktiboaren oinarriak}

Gaur egun eskola aktibo terminoaz ezagutzen direnak ikaslearengan oinarritutako hezkuntzaren barnean kokatzen dira. Terminoak barne hartzen duen unibertsoa zabala da oso, oinarri eta ezaugarri anitzak biltzen dituelako.

\subsubsection{Ikaskuntza indibidualizatua eta autonomoa}

Jakintza ekintzari lotua dago, pertsonak inguratzen duen munduari buruz egiten dituen operazio eta eraldaketei (Delval, 1996). Horren ildotik, Piaget psikologoak (1987) aipatzen zuenez, ekintza aktibitate intelektual ororen oinarria da; haur txikienek egiten dituzten ekintza espontaneo eta behagarritik hasi, eta operazio intelektual konplexuetaraino. Ondorioz, irakaskuntza haurraren interes eta beharretara egokitzen denean, prozesua askoz ere aberasgarriagoa bilakatzen da.

Nagusiki, eskola-antolaketa tradizionalak honako ideia honi jarraitu izan dio, Hoyuelosen (2010) arabera: guztiok berdin eta batera. Baina bakoitzaren bizitzako erritmoak desberdinak dira eta horregatik haur bakoitzari behar duen denbora eman behar zaio aurreratu gabe.

Haurra gai da modu autonomoan ikasteko, gaitasun motorrari dagokionean, eta baita esperientzia aktiboak jaso eta bere buruaren ezagutzan aurrera egiteko aukera duenean ere (Herrán, 2013; Tardos, 1992). Ondorioz, haur batek bere kabuz ikas dezakeen hori irakasten jardutea, alferrikakoa izateaz gain, haurrarentzat kaltegarria da, Pikler-Loczy (1984) institutuan uste duten bezala.

Haur txikien garapena, Rebeca Wild (2007) pedagogoarentzat eta Pestalozzi eskolentzat, haren behar afektiboen eta sentsorialen, eta motrizitatearen asebetetzearekin lotuta dago. Alabaina, sistema horiek egituratuko dira ondorengo bi esperientziak gertatzen badira: haurrak atentzio eta mai- 
tasun gosea izatea eta esperientzia motorrak zein sentsorialak bizitzeko gogoa izatea.

Hezkuntzaren benetako funtzioak, Maria Montessori (1986) psikologo eta zientzialariarentzat, honako hau izan beharko luke: haurrak berezkoak dituen gaitasunak garatzeko giro egokia sortzea. Haurrak jakintzak barneratzeko eta bere burua hezteko ahalmena du, horretarako espazio eta materialak eskaintzen bazaizkio.

Reggio Emilia eskoletan ere, garrantzi berezia ematen zaio «giroari». Eredu horien bultzatzailea izan den Loris Malaguzzi pedagogoak «giroa» hirugarren hezitzailea dela esan zuen (Beresaluce, 2009; Edwars, Gandini, eta Forman, 1993).

Bestalde, Wallon (1942), Vygotski (1979) eta Piaget (1987) psikologo ospetsuek - eta gaur egungo hainbat autorek, hala nola Ruiz de Velasco eta Abad (2011), eta Alvarez-Uria, Tresserras, Zelaieta eta Vizcarra (2015) - , behin eta berriz azpimarratu dituzte jolasak dakartzan onurak haurren osasunean eta ikaskuntzan. Ez dago jolasaren parekorik oreka emozional eta energetikoa lortzeko eta, era berean, gaitasun intelektuala, soziala eta sormena lantzeko (Freire, 2011).

Jolasaren bidez, eta bereziki jolas sinbolikoaren bidez, haurra barrenbarreneko beharrekin eta ingurunearekin kontaktuan jartzen da. Horretarako, ezinbestekoa da modu librean, espontaneoan eta autorregulatuan jardutea, jolaste hutsaz gozatzea beste helbururik gabe (Freire, 2011).

\subsubsection{Ikaskuntza globalizatua}

Psikologo eta pedagogoek haurrak gauzak interesatzen zaizkion moduan ikusten eta adierazten dituela baieztatzen dute. Osotasuna interesatzen zaio, dena batera ikusten du (ikuspegi sinkretikoa) eta, horregatik, pertzepzio orokorrak ditu (Laguía, 2008). Beraz, haurrak modu globalean ikasten du, kuriositatea pizten duen guztiak haren interesa sortzen du eta alderantziz (Decroly, 1987). Irakasleak interes horiek antzeman behar ditu, ikasleen interesa eta motibazioa zenbat eta handiagoa izan, ikaste prozesuaren erdiespena are errazagoa izango delako (Pareja, 2011).

Neurozientziaren korronteetara joz gero, gizabanakoon oinarrizko joerak edo bulkadak honako hauek dira: orientazioa, esplorazioa, ordena, abstrakzioa, irudimena, lana/manipulazioa/mugimendua, perfekzioa, zehaztapena, errepikapena, norbere buruaren kontrola eta komunikazioa. Hala, haur txikiak ingurunea bere zentzumenen bidez esploratu behar du eta bere burua objektuekin, pertsonekin eta fenomenoekin harremanean kokatuko du.

Reggio Emilia eskoletan, adibidez, etengabe oinarritzen dira hausnarketa propioan eta ekintza praktikoan, eredu hierarkizatua eta modu lineal batean proposatzen diren marko eta helburu didaktikoak alde batera utziz (Zabalza, 1996). Azken batean, ikaskuntza sakonena eta denbora luzeagoz 
gogoratuko dena aktiboki praktikatzen eta esaten dena da, esperientzia zuzenak ematen diguna, alegia (Dale, 1964).

Zentzu horretan, eskola aktibo bateko irakaslea irakasle «pasibo» terminoaz ezagutzen da. «Reggio Emilia eskolako irakaslearen esku-hartzeek trebeak, delikatuak, isilak, ez-izugarriak izan behar dute; nahikoa da haurrek bere presentzia sentitzea, berarekin daudela. Horrek gertatuko denaren inguruko konfiantza eta kontzientzia ematen die eta ikasten dute» (Hoyuelos, 2004, 172. or.).

Ebaluazioaren ikuspegitik, beraz, ebaluazio prozesuala eta sistematikoa aldarrikatzen da nagusiki (Fisher, 2008; Paniagua eta Palacios, 2005). Prozesuan zehar ebaluatzeak unean uneko egoeraren berri eman eta erabakiak hartzea ahalbidetzen du (Barandiaran eta Larrea, 2016).

\subsubsection{Bizipenei lekua}

Haurra zirrara eta emozioz beteta dagoen izakia da, eta bere egonezinak, momentu atseginak edota deserosoak modu horretan agertzen ditu. Aucouturier-en (2012) arabera, hori haurraren oreka psikologikorako positiboa da. Irakaslearen ardura izan behar da haurrari laguntzea bere emozioak adierazten, izena jartzen, identifikatzen eta, agian, bere familia edota eskola-testuinguruaren arabera ulertzen ere bai.

Zentzu horretan, bizipenezko psikomotrizitateak haurrari bere emozioak askatzeko, eta progresiboki erreprimitu gabe arintzeko aukera ematen dio (Aucouturier, 2012). Baina, horretarako, Lapierre eta Aucouturier-en hitzetan (2012), «aktibitateak ez programatzea, dagoen dinamikaren arabera inprobisatzea eta haurren bizipenetan interesa edo atentzioa jartzea» beharrezkoa da (Pastor, 2002, 221. or.).

\subsubsection{Eskola dinamikoa eta dokumentazioaren garrantzia}

Eskolak garai berrietara egokitua izan behar du eta, horregatik, garrantzitsua da hezkuntzaren inguruan hausnartzen jardutea, eta berritzea.

Kasu askotan dokumentazioaren bidez irekitzen da hausnarketaren bidea, dokumentatzeak lanarekiko distantzia hartzea ahalbidetzen duelako (Hoyuelos, 2007). Dokumentatzerakoan, irakasleak, hezkuntza proiektuari buruz hausnartzeko eta irakaspenak berrikusi - ikuspuntu berri bat sortueta eztabaidatzeko aukera du.

Baina dokumentatzearen garrantzia harago doa: «dokumentazioa haurrarentzat baliagarria da honetarako: autoebaluaziorako, bere burua ezagutzeko, bere ekintzei zentzua aurkitzeko, hausnarketarako, bere buruaz oroimena izateko eta interpretazio bakarrera mugatua ez izateko. Familiari, berriz, hitzak ikusteko aukera ematen dio, haurraren prozesuek aurrera nola egiten duten ikusteko (produktuak soilik ez baloratzeko), eta euren seme-alaba hobeto ezagutzeko» (Hoyuelos, 2007, 6. or.). 


\subsubsection{Eskola eta familiaren arteko elkarlana}

Gauza nabaria da haurra ez dela eskolan izaki isolatu bat. Haur bakoitza bere inguruneko partaidea da, eta horrela ulertzen du, esaterako, pedagogia sistemikoa deitutako korronteak. Bestalde, hezkuntza ekosistema bat da: familia-, gizarte-, kultura-egitura edota historiari lotuta dago eta horrek irakaskuntza-ikaskuntza prozesuetan eragina du (Traveset, 2007).

Pedagogia sistemikoaren helburua pertsona bakoitzari lekua ematea da, bakoitzak dituen egitura desberdinak aintzat hartuz. Horretarako, eskola erakundeen eta familiaren arteko elkarlanek hezkuntza prozesuaren oinarri izan behar dute (Olvera, 2009).

Malaguzziren arabera (Edwars, Gandini eta Forman, 1993), eskola bizirik dagoen erakunde bat da, osoa, helduek eta haur ugarik bizitza eta erlazioak partekatzen dituzten toki bat. Italiako Reggio Emilia eskoletan familia hezkuntza-errekurtso bat dela uste da eta eskolaren gestioan familiek zintzoki parte hartzeko eskubidea aldarrikatzen dute (Beresaluce, 2009).

\subsubsection{Naturarekiko harremana}

Ingurunearekin harremanak eta aire librean egindako jolasak haurraren osasun eta ongizatea hobetzen laguntzen dute: autoestimua handitzen dute, kontzentrazio gaitasuna garatu, irudimena eta autonomia landu, baita gaitasun kognitiboak eta arrazoinamendua ere, estres egoerak gutxitzen dituzte eta haurra gutxiago gaixotzen da. Errealitatea, berriz, ez doa ikerketa horiek diotenaren ildotik: 70eko hamarkadatik hona, haurrek denbora librerako astean 15 bat ordu gutxiago dituzte eta soilik \% 29k du aire libreko jolas eta abenturetarako tartea (Freire, 2011).

Gaur egungo haurrek bizi duten natura-faltari aurre egiteko eta zuzeneko ingurumen-esperientziak eskaini nahian, zenbait hezkuntzaproiektu basoetara bertara eraman dira: Skogmulle eskolak Eskandinavian, Waldkindergarten ekimenak Alemanian edota The secret garden eskola Eskozian.

Era berean, ikastetxeak naturara gerturatzeko beste hamaika proiektu garatzen ari dira munduan zehar. Hala, mundura gerturatzeko eta hobeto ulertzeko bitarteko gisa erabiltzen da paisaia, eta aldi berean, ekologiarekiko jarrera positiboa sustatzen da, eta gizakiaren alderdi kognitiboez gain, intuizioa, emozioak eta sentikortasuna lantzen dira (Freire, 2011).

\section{HELBURUAK}

Bizilore hausnarketetatik eraikitzen ari den eskola aktiboa da, eta, hain zuzen ere, horregatik aztertu nahi dira eskola komunitate horren lehen urratsak, ikaslea bere ikasketa prozesua modu esanguratsu eta aktiboan eraiki- 
tzeko diseinatzen dituen metodologiak eta praktikak berebiziko garrantzia izan dezaketelako. Hala, helburuak honako hauek dira:

1. Azkoitiko Bizilore eskola eta komunitatearen eredua nola egituratzen den ezagutzea eta, eskola aktibo eredu gisa, filosofia eta printzipio teorikoak modu praktikoan eta eguneroko jardueretan nola gauzatzen diren aztertzea.

2. Eskola aktibo baten oinarrietan sakontzea, eta gisa horretako eskoletan erabiltzen diren metodologiak, gune egokituak eta material didaktikoak identifikatzea.

\section{METODOA}

Bizilore eskola aktiboaren hastapenak ezagutzeko hezkuntza-etnografia bat eraman da aurrera. Hartara, narratibaren bidez, hainbat gairen inguruan, kasu honetan eskola-proiektu berri baten inguruan, pertsonek eduki ditzaketen esperientziak, bizipenak eta pertzepzioak sakontasunez ezagutzeko aukera izan dezakegulako (Juaristi, 2003).

\subsection{Testuingurua eta parte-hartzaileak}

Ikerketa honen jomuga Azkoitian (Gipuzkoa) kokatuta dagoen Bizilore eskola aktiboa da. Eskolak, eragile desberdinen lanaren ondoren, 2014an ireki zituen ateak. Gaur egun, Haur Hezkuntzako etapan egiten dute lan eta eskola komunitatea 3-6 urte bitarteko 12 haurrek, euren familiek, bi hezitzailek eta pedagogo batek osatzen dute. Aurrera begira, epe motzean, Lehen Hezkuntzako eskaintza zabaldu nahi dute eta, epe luzeagoan, ez dute baztertzen Derrigorrezko Bigarren Hezkuntza abian jartzea.

Lan honekin eskola komunitate berri horren hastapenak ezagutu eta aztertu nahi izan dira eta, horretarako, eskolako eragile guztiek hartu dute parte. Modu zuzenean (elkarrizketen bidez) Biziloreko bi bidelagunek parte hartu dute. Bestalde, eskolako 3-6 urte bitarteko haurrek, talde pedagogikoak eta hainbat gurasok funtsezko laguntza eman dute ikerlana burutu ahal izateko. Ikerketa 2016ko ekainetik azarora bitartean gauzatu da.

\subsection{Teknikak eta tresnak}

Behaketa egiteko teknika etnografikoak erabili dira. Horiei esker, ikertzaileak testuinguruko informatzaileekin harremana izan du eta elkarreragineko datuak modu sistematikoan eta ez intrusiboan lortu dira (Taylor eta 
Bogdan, 1992). Edozein etnografiatan bezala, behaketa egin bitartean, ikertzailearen landa-koadernoan oharrak eta hausnarketa pertsonalak jaso dira: ikaskuntza indibidualizatua eta globalizatua gauzatzeko oinarri metodologikoen inguruan; eskolaren egunerokotasunean bizipen eta emozioek duten garrantziaren inguruan; eskola eta familiaren arteko elkarlan ereduaz; edota naturarekiko kontaktuak duen protagonismoaz. Eskolaren eguneroko zenbait momentu, gainera, argazki zein bideo bidez dokumentatu dira, informazio esanguratsua eman dezaketelako (Latorre, 2003).

Bestalde, elkarrizketa ez-zuzenaren bidez, Bizilore eskolako bidelagunen funtzioak eta pertzepzioak jaso dira, «mundua, bizitza, eta ondo ezagutzen duten arloa nola ikusten, sailkatzen eta bizi duten» ezagutuz (Juaristi, 2003 , 139 or.). Elkarrizketetatik jasotako informazioa (kategoriatan identifikatutako gaien inguruko galderen bitartez), eskolari lehen hurbilpena egiteko eta, bereziki, oinarri pedagogiko eta metodologikoetan sakontzeko esanguratsua izan da.

Azkenik, materialen azterketatik informazio baliagarria eta hainbat ondorio atera dira. Horrela, ikertzaileak beste batzuek euren gogoz edo beharrez «sortutako» materialaren gainean lan egiteko aukera izan du (Juaristi, 2003).

\subsection{Prozedura}

Etnografia gisa, azterketa barrutik egin da, testuinguruan murgilduta, alegia. Bizilore eskola komunitate sortu berriak aurrera eramaten duen ikaskuntza-prozesuaren ebidentziei buruzko narrazio koherentea eraiki nahian, eskolaren barru-barrutik eraikitzen den diskurtsoa egunerokotasunean behatu, bidelagunak elkarrizketatu eta materialaren azterketa egin da. Hala, behin deskribapenak eta gertaerak jasota daudela analisia egin da. Analisia egin ahal izateko eta oharren bidez jasotako ebidentzia narratiboak sailkatzeko, kategoria-sistema bat sortu da, eta hori analisi-tresna bilakatu. Testu narratiboen analisi unitateak kategoria-sistema horren arabera sailkatu dira. Horrela, kategoria-sistema, hierarkizatuta dagoenez, ebidentzia narratiboak eta argazkiak sailkatzeko, emaitzen diskurtsoa egituratzeko baliagarria da. Ondorioz, kategoria-sistema induktibo-deduktiboa da, hasierako kategoriak teorian oinarrituta zeudelako eta jasotakoarekin eraldatu direlako. Ostean, lortutako datu guztiak uztartu eta triangelukatzearen bidez kontrastean jarri dira.

Landa-koadernoan jasotako oharrak identifikatzeko (LK) kodea erabili da eta elkarrizketetatik baliatutako hizketaldi eta ahotsak identifikatzeko, berriz, ondorengo kodeak: $(\mathrm{H})$ haurra; haur bat baino gehiago $(\mathrm{HK})$; bidelagunak (IB eta MB), bakoitzari bere izenaren lehen hizkia ezarriz; eta pedagogoa (P). Horiek guztiak, behaketako datuekin batera, aldez aurretik zehaztutako kategorien arabera sailkatu eta aztertu dira (1. taula). 
1. taula

Analisi-tresna: kategoria-sistema

\begin{tabular}{l|l}
\hline \multicolumn{1}{c|}{ Kategoria } & \multicolumn{1}{c}{ Azpikategoriak } \\
\hline \multirow{4}{*}{ Ikaskuntza indibidualizatua } & Ratio eta lan-taldeak \\
\cline { 2 - 2 } & Jolas librea \\
\cline { 2 - 2 } & Gune girotuak \\
\cline { 2 - 2 } & Materiala \\
\cline { 2 - 2 } & Ebaluazio pertsonalizatua \\
\hline Ikaskuntza globalizatua & Haurren parte-hartzea \\
\cline { 2 - 2 } Bizipen eta emozioei lekua & Bidelagunen funtzioa \\
\hline Eskola dinamikoa & \\
\hline Eskola eta familiaren arteko elkarlana & \\
\hline Naturarekiko kontaktua & \\
\hline
\end{tabular}

\section{EMAITZAK}

Jasotako informazio guztiak harreman estua izan arren, marko teorikoarekin koherentziari eutsi eta irakurketa paraleloa lagundu nahian, emaitzen atala informazioa sailkatu eta aztertu den kategorien arabera aurkeztuko da. Emaitzen atalean Bizilore eskolaren oinarri pedagogikoak (ikaskuntza indibidualizatua, globalizatua eta bizipenei lekua) eta metodologikoak (ratioak, lan-taldeak, jolas librea, gune girotuak, materiala eta ebaluazioa) identifikatu eta eskolaren egunerokotasunean aurrera eramateko antolakuntza eredua (eskola dinamikoa, eskola eta familiaren arteko elkarlana eta naturarekiko kontaktua) deskribatu eta ezagutzera emango dira.

\subsection{Ikaskuntza indibidualizatua}

Biziloreko bidelagunek eskainitako elkarrizketan azpimarratzen dutenez, haur bakoitza ezberdina eta errepikaezina da, horregatik, eskolan, egunero, bakoitzaren ezaugarriei erreparatzen ahalegintzen dira.

«Haur bakoitza ezberdina eta errepikaezina da eta bakoitzaren ezaugarriei erreparatzen diegu gure egunerokotasunean.» (MB) 
Erritmo desberdinak daudela onartzen dute eta, horiek errespetatu ahal izateko, metodologia aktiboak erabiltzen dituzte. Hartara, egiten dituzten proiektu eta lantegietarako behar indibidualak zein taldearen ezaugarriak kontuan hartzen dituzte.

Baina ez dira gutxi Bizilore eskola aktiboan ikaskuntza indibidualizatua bermatzeko jarraitzen dituzten oinarri metodologikoak. Lehengo eta behin, ratioa asko zaintzen da, adin-tarte bakoitzeko bost ume. Horrek haurrak talde txikitan eta helduen esku-hartze zuzenik gabe lan egitea ahalbidetzen du. Horren adibidea da inork esan gabe, euren ekimenez, hamaiketakoan erabilitako ontziak garbitzen dituztela.

«Hiru adin elkartzen direnean behar da hezitzaile bat egotea, eta gure kasuan, etapetan elkartzen ditugunez, guztira 15 ikasleko taldea izango litzateke eta bi bidelagun. Gero, eskolako pedagogoa egongo litzateke baita ere egunero eskolan, eta askotariko funtzioak betetzen ditu.» (MB)

Era berean, haur bakoitzarengan zentratutako ikaskuntza horretarako, jolas librea, gune girotuak, materialaren prestaketak eta ebaluazio pertsonalizatuak ezinbestekoak dira.

\subsubsection{Jolas librearen garrantzia}

Behatutako testuinguruan ikaskuntza indibidualizatua bermatu ahal izateko jolas libreari ematen zaion garrantzia ikusi da. Irakaskuntza haurraren behar eta interesetatik abiatzeko, jolas libreak aparteko garrantzia hartzen du eguneroko dinamikan Biziloren. Haurrak, sartu bezain laster, nahi duen espazioa aukeratzen du bere jolasa egiteko eta, horrela, norbere garapen kognitibo eta sentsorio-motorrean aurrera egiteko.

Behaketa lanean ikusi da, une oro, haurra dela jolas edo ekintzak aukeratzen dituena. Horregatik, gela eta memento berean egoera ugari gertatzeko aukerak sortzen dira (ikusi 1. eta 2. irudiak).

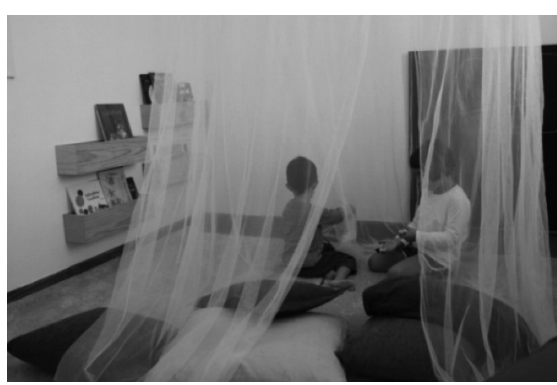

1. irudia

Haurrak interpretazioko txokoan txotxongiloekin jolasean

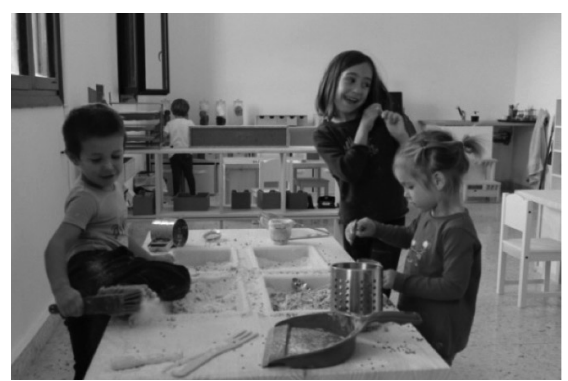

2. irudia

Haurrak esperimentazio eremuan «lanean» 
Egoera horietan, bidelagunak presentzia eta beharrezko laguntza bakarrik eskaintzen ahalegintzen dira. Gainera, prozesuan sinesten dute, produktuan edo emaitzan baino gehiago.

«Ez gara produktura edo emaitzara mugatzen. Guretzako haurrak egiten duen prozesua da garrantzitsua eta saiatzen gara eskolako komunitatea osatzen dugunoi hori transmititzen.» (IB)

Adibidez, haur baten helburua kanpo espazioan kokatuta dagoen etxetxora igotzea bada, behar duen denbora ematen zaio bere kabuz lor dezan, nahiz eta horretarako bi hilabete behar izan (ikusi 3. irudia).

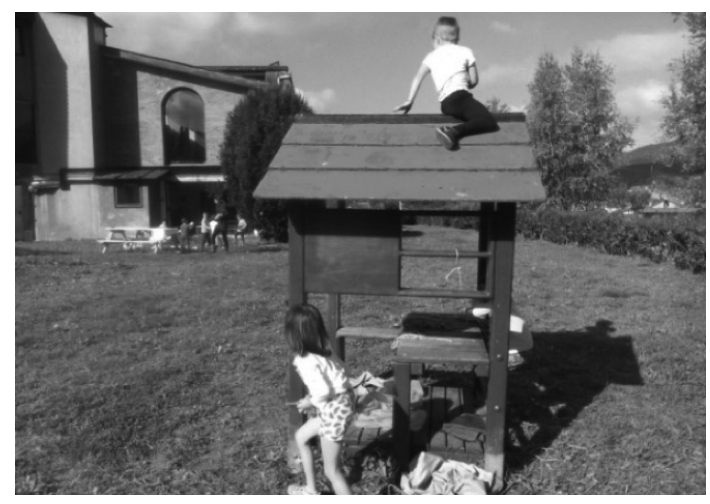

3. irudia

Haurra bere ahaleginaren ondorioz etxetxora igota

Bidelagunek prozesuan lagunduz gero, haurrak denbora gutxiago beharko luke bere helburua lortzeko. Baina helburua bere ahaleginaren ondorioz lortzeak, plazer handia eta ahalduntzea eskaintzen dio, prozesua protagonista bilakatuz.

\subsubsection{Gune girotuak}

Biziloren, baliabide egokiak izanda, haurrek euren ikaskuntza propioa barnetik sortuko dutelako konfiantza dute, baina, horretarako, beharrezkoa da espazioa kontu handiz prestatzea: umeengan eta umeentzako pentsatuta. Eskola barruko eta kanpoko espazioetan banatuta dago, bertan interesguneak daude, lantegiak eta txokoak, eta oso ohikoa da haurrak modu autonomoan lanean ikustea.

\subsubsection{BARRUKO ESPAZIOA}

Eskolako eraikinaren barrualdea gune eta giro desberdinez osatua dago: esperimentazio eta mugimendu gelak, korridoreak, espazio komu- 
nak... Jasotako informazioaren arabera, ondorengoak dira barruko espazioan identifikatu eta deskribatzen diren baliabideen guneak: harrera, mugimendua, eraikuntza, artea, montessori, sukaldea eta jangela, eta natura, hain zuzen ere.

\section{Harrera gunea}

Sarrera eta irteeren eremua eraikinaren goiko partean dago. Sarrera askea da Biziloren, 9etan argiak piztu eta haurrak beren erritmora sartzen dira: txamarra erantzi, eskolako zapatilak jantzi eta prest daudenean jolastera sartzen dira. Bidelagunak sarrerara gerturatzen dira, eta haurrek eta gurasoek elkar agurtzen dituzte. Irteera, berriz, ordu batean egiten dute, eremu berdinean. Sarrera-irteerako uneak bidelagunen eta gurasoen arteko elkarrizketetarako eta informazioaren eguneroko trukea egiteko erabiltzen dituzte.

\section{Mugimendu gunea}

Eraikin barneko espaziorik zabalena da eta harreman gehienak bertan ematen dira. Mugimendua umearen garapenaren ardatz garrantzitsua denez, gune honetan, haurrek mugimendu askatasunari eta beharrari erantzuteko baliabide ugari eskura dituzte. Egiten dituzten jolasen artean honako hauek daude, besteak beste: horma bota, horma-barrak igo eta jaitsi, saltoak eta jolas sinbolikoa (ikusi 4. irudia).

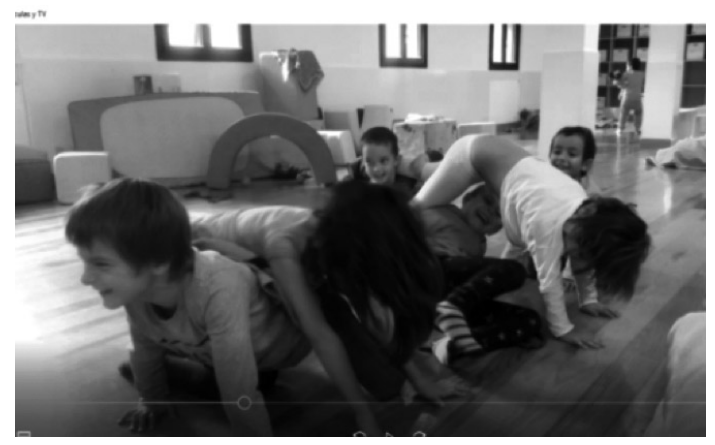

4. irudia

Haurrak mugimendu gunean jolasaren bidez harremanak lantzen

\section{Eraikuntza txokoa}

Eraikuntza txokoak haurrari eraikitzeko aukera eskaintzen dio, horrela, bere garapenean aurrera egiteko aukera emanez. Mugimendu gunearen on- 
doan kokatzen da eta honako materialez osatuta dago: egurrezko blokeak, makilak, sokak, oihalak, kortxoak eta abar.

Arte gunea

Eskulanak egiteko espazioa da. Mahai zabal batez eta haurrak eskura dituen material ugariz osatuta dago: margoak, guraizeak, paper mota asko, kartoi meheak, oihalak, hariak eta josteko tresnak (ikusi 5. irudia).

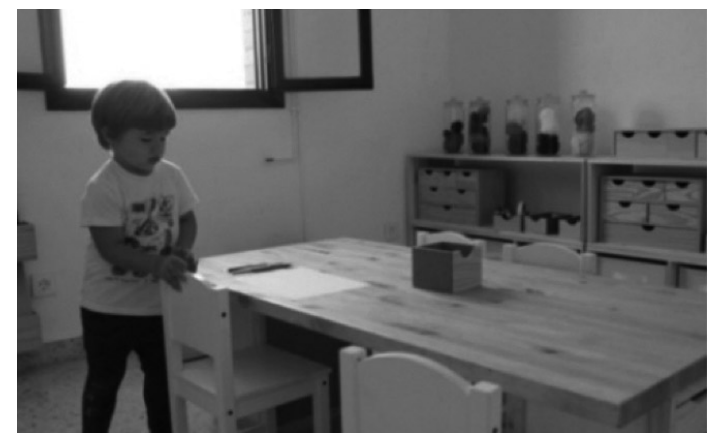

5. irudia

Ikasle bat arte gunean «lanerako» prestatzen

Montessori gunea

Bizitza praktikoko eta egurrezko material sentsorialez osatuta dago. Materialak funtzio autozuzentzailea du eta haurren neurrira egokitua dago. Haurrei aukera ematen die, ikaskuntza globalizatuaren bidez, matematikako, natur baliabideetako, geografiako, zein idazketa-irakurketako gaitasunetan trebatzeko (ikusi 6. irudia).

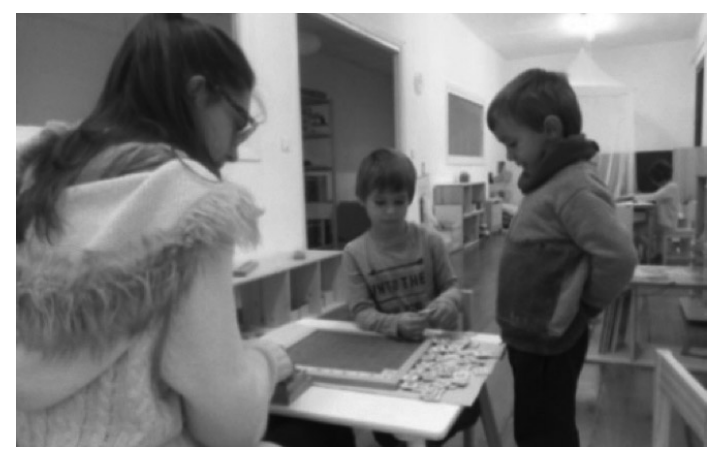

6. irudia

Bi ikasle bi bidelagunen konpainian Montessori gunean zenbakiak lantzen 
Sukaldea eta jangela

Sukaldea eta jangela eremua ere haurrek autonomiaz jarduteko egokituta dago eta, jateko autonomia ez ezik, sentsorialtasuna, jateko ohitura kulturalak eta harremanak ere garatzeko balio du. Haurrak askatasuna du elikadura guneko ekintza guztietan: dagoen eskaintzatik zer eta zenbat jango duten erabaki, janaria mahaira eraman, ura bete, esku zapia hartu, bukatzean bakoitzak erabili duena jaso eta harrikoa egin (ikusi 7. eta 8. irudiak).

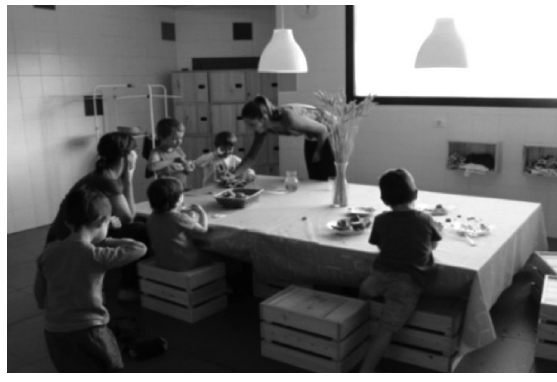

7. irudia

Hamaiketakoa egiten, bidelagunaren eta guraso baten konpainian

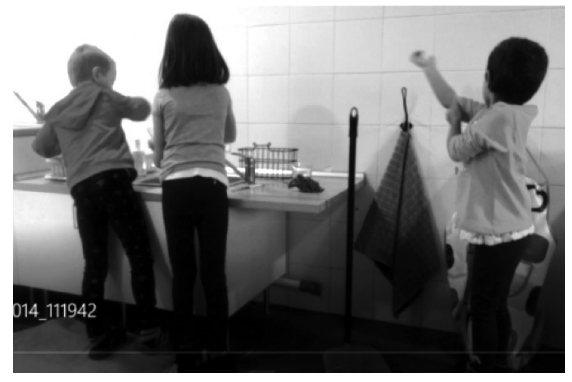

8. irudia

Haurrak euren ekimenez ontziak garbitzen

Natur baliabideen eremua

Eraikinaren beheko partean kokatua dago eta kanpo espazioarekin konexio zuzena du. Lurraren ekosistema desberdinak esperientziaren bidez ezagutzeko prestatutako eremua da eta, horretarako, haurrek era askotako material natural eta objektuak dituzte eskura: adibidez hondarra, belarra, lurra edo ura (ikusi 9. eta 10. irudiak). Gainera, horiei buruz sakontzeko informazio-iturri osagarriak dituzte, liburuak eta aldizkariak, esaterako.

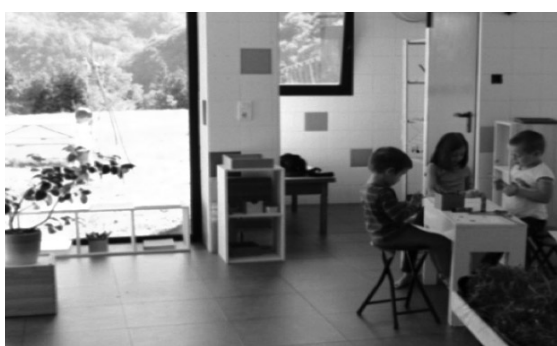

9. irudia

Ikasle batzuk natur baliabideen eremuan «lanean» eta, aldi berean, kristalaren beste aldean, haur batzuk jolasean

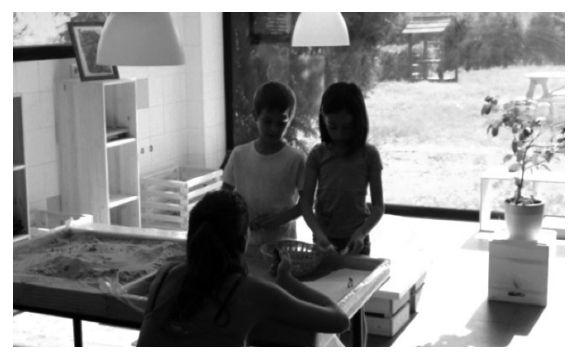

10. irudia

Era askotako material natural eta objektuak haurren eskura 


\subsubsection{KANPOKO ESPAZIOA}

Bidelagunen elkarrizketetan jasotakoaren arabera, garrantzi berezia izan du eskolaren eraikin berriaren hautaketan kanpoko espazioak, eta, ikerketa lanean, aukeraketa horren emaitzak agerikoak dira.

Biziloren kanpoan jolasteko eremu zabala dago eta oraingoz, hiru eremutan banatuta: sarrera-irteerak egiten diren eremuaren ondoko zelaitxoa, goiko espazioa eta behekoa. Goiko espazioan hondartegia, mahaiak eta aulkiak, zabu bat, zenbait fruta-arbola, zuhaixkak eta uraren txorrota daude (ikusi 11. irudia). Beheko espazioan zelaigune handia dago, baita egurrezko mahai bat eta egurrezko etxetxo bat ere (batik bat, aterpe gisa, edota gora igo ahal izateko erabiltzen dena) (ikusi 12. irudia).

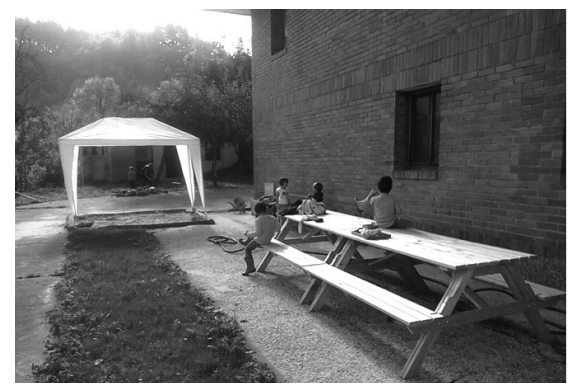

11. irudia

Goiko espazioa

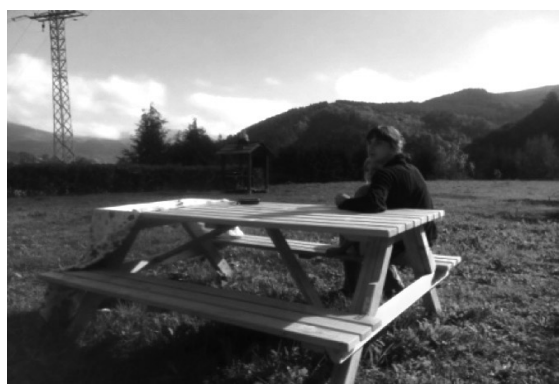

12. irudia

Beheko espazioa

Kanpoko espazioak gune girotuak dira eta espazioaren ordena orokorrari eusten diote ere bai, materialak umeen beharren arabera alda daitezkeelarik. Horri esker, haurrek erosotasunez eta hainbat modutara esploratu dezakete mundu fisiko, biologiko eta soziala.

\subsubsection{Materiala}

Materiala bereziki zaintzen da Biziloren, kontu handiz aukeratzen da eta proposamen metodologikoaren alderdi garrantzitsua da. Aukeratutako materiala haurren neurrikoa izan ohi da eta eskura jartzen zaie, modu errazean erabili eta manipulatu ahal izateko (ikusi 13., 14. eta 15. irudiak).

«Materialek ezin dute izan ez oso errazak, segituan aspertzen direlako, baina ezta oso zailak ere, frustrazioak eragiten dizkielako horrek. Materialak haurrari egokitua izan behar du eta ahal den neurrian, material ez egituratua erabiltzen saiatzen gara.» (MB) 


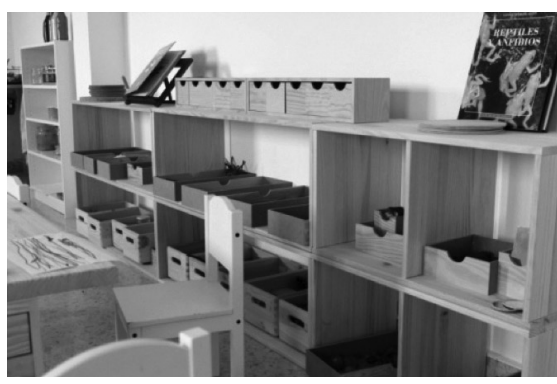

13. irudia

Materiala modu ordenatuan sailkatuta

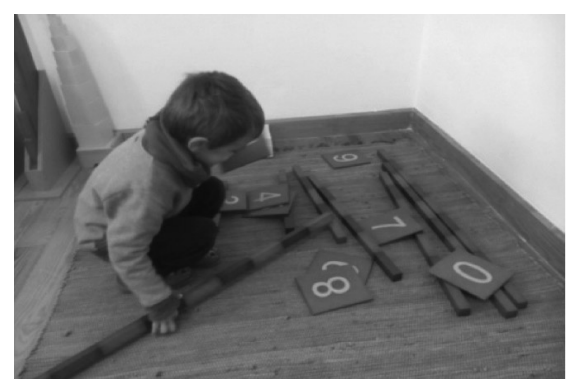

14. irudia

Haurra Montessori materialarekin lanean

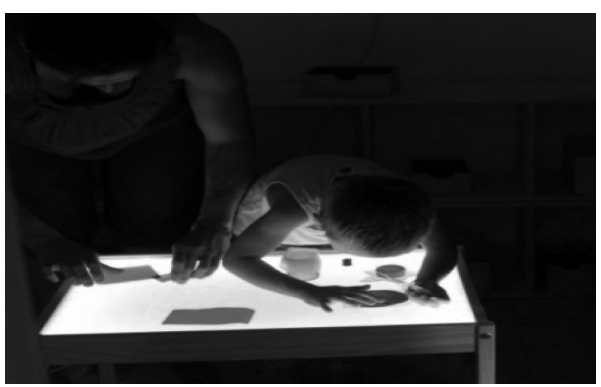

15. irudia

Haurra argi mahaiarekin eta formekin esperimentatzen

Materiala bidelagunek prestatu eta antolatu ohi dute, eta behaketen bitartez erabakitzen dute helburuak betetzen dituen edo ez, haurraren interesekoa den edota ezaugarriak aldatu behar zaizkion. Errekurtso materialak ugariak dira eta gainera, horietako asko gurasoek egindakoak dira.

\subsubsection{Ebaluazio pertsonalizatua}

Behatutako testuinguruan ebaluazioa jarraitua eta sistematikoa da. Bidelagunek ebaluazio pertsonalizatua gauzatzeko etengabeko behaketa burutzen dute. Ohar garrantzitsuak momentuan bertan jasotzen dira (ikusi 16. irudia) eta horiek konpartituak izan ohi dira haurrarekin esku hartzen duten bidelagun eta profesionalen artean. 


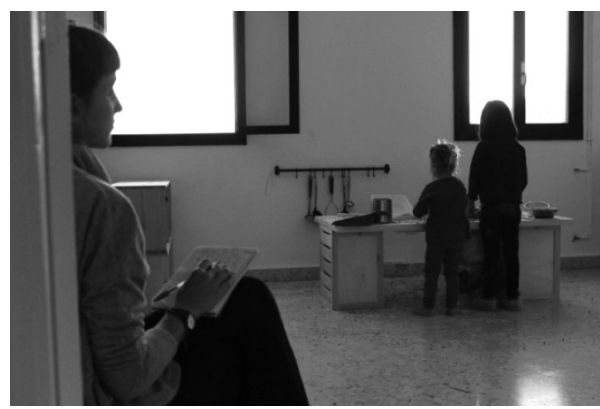

16. irudia

Bidelaguna haurrak behatzen eta oharrak hartzen

Horrekin batera, hiru hilabetean behin, haur bakoitzaren jarraipen-txostena egiten da.

«Guretzat garrantzitsua da informazioaren transbase hori egitea haurra eskolara sartzean zein irtetean. Horrekin batera, umeak behar badu familiaren kontaktua eskolan dagoen bitartean, deitu egiten zaio. Biziloren ez da derrigorrezkoa egunero etortzea. Hori bai, haur bat hasten bada astean bitan ez etortzen, adibidez, horrek lanketa bat egin beharrean jartzen gaitu: zer pasatzen da? Zerbaitetan huts egin da?Aztertu beharrekoa izango litzateke hori guretzat.» (IB)

Dokumentuan eskolako martxa orokorra jasotzen da eta guraso zein Biziloreko gainerako kide interesatuentzat ikusgai jartzen da. Era berean, gurasoekin harreman zuzena izaten saiatzen dira egunero, sarrera-irteeretan, eta hiru hilean behin gurasoekin egiten diren bileretan.

\subsection{Ikaskuntza globalizatua}

Ikaskuntzaren izaera globalizatzaileari erantzuna emateko, haurrek eskolako dinamikan modu aktiboan parte hartzeko dituzten bideak eta ikaskuntza ulertzeko modu horri erantzuteko bidelagunak hartu beharreko rola identifikatu eta aztertu dira.

Biziloren denborak ez daude ikasgaika antolatuta eta haurrak inguru fisiko, biologiko eta soziala modu aktibo eta anitzean esploratzera animatzen dituzte, ikaskuntzaren izaera globalizatzailea sustatuz. Ikuspegi hori aurrera eramateko, hainbat metodologia aktibo jarraitzen dituzte; haurren parte hartzerako topaguneak edota esperientzia zuzenetatik abiatutako jakintza sustatzea, esaterako.

Biziloreren lan-oinarriak ikaskuntza esanguratsua (errealitatearekin konektatua) eta diziplinartekoa (sare baten antzera ikaskuntza bakoitza beste 
ikaskuntzekin lotura zuzena) dira. Haurren parte-hartze erreala sustatzen saiatzen dira; haurrek proposatzen dutena egiten ahalegintzen dira eta haurrek, poliki-poliki, maila desberdinetan (bakoitzaren arabera), ekintzak antolatzen jarduten dute. Esate baterako, haur batek proposatzen badu Biziloreren eraikin zaharra ikustera joatea, proposamena jaso eta gauzatzen saiatuko dira.

«Berez, funtzio horretarako sortu genuen (topagunea), baina aitortu behar dugu batzuetan ez duela funtzionatzen edo ez direla beti proposamenak eta iritziak jasotzen. Gehiago izan ohi dira "amonaren etxera noa bazkaltzera" eta horrelakoak.» (MB)

Behaketa jarraituari esker bidelagunek haurren proposamenen eta beharren berri izaten dute baina bada horiek detektatzeko beste modu bat: topagunea (ikusi 17. irudia). Topaguneko momentuan bakoitzak nahi edo behar duena esateko aukera du. Haurrak askatasunez erabakitzen du bertan parte hartu nahi duen edo ez.

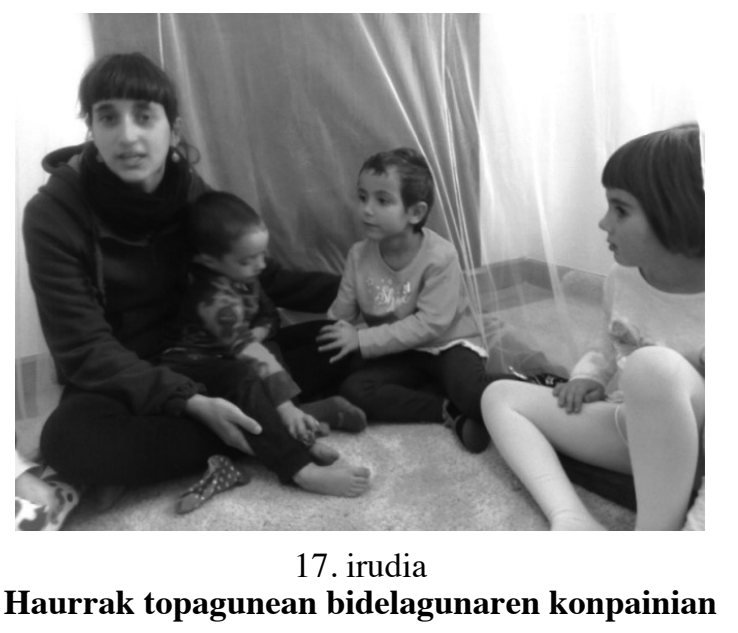

Badira topagune bereziak ere bai. Bertara haurrak deitzen dituzte erabakiren bat adostu behar denean eta horietan parte hartzea derrigorrezkoa izan ohi da.

«Haurrei lehenago abisatzen diegu "gaur erabaki bat hartu behar dugu eta horretarako topagune berezi bat egingo dugu geroago". Horrela, eurei ere denbora ematen diegu prestatzen joateko. Adibidez, espazioan aldaketak egitekotan gara, baina nahi dugu aldaketa horien inguruko iri- 
tziak eta ekarpenak jasotzea haurrengandik zuzenean, ba horretarako topagune berezi bat egingo dugu.» (IB)

Bestalde, ikaskuntza globalizatua ulertzeko modu horri erantzuteko, bidelagunak hartu beharreko rola ere garrantzitsua da. Haur bakoitzaren interes eta beharrak behatzea da bidelagunen funtzioa eta ardura nagusia, horien araberako dinamikak, ekintzak edota materialak eskaintzeko. Esaterako, ikasleek komunean igel bat topatzen badute, aurkikuntza aprobetxatu eta igelen bizitza, habitata, bizi-zikloa eta abar lantzen da. Azken finean, jakintzak esperientzia propioetatik abiatuta esanguratsuagoak dira. Hala ere, gertakari batek haurrengan zirrara desberdinak eragin ditzakeela kontuan hartzea garrantzitsua da.

«Talde guztiari ere erreparatu behar diozu aldi berean. Igela agertu zenetik haur batek beldurra hartu zion, esaterako, komunera joateari pentsatzen zuelako igela han egongo zela. Azkenean, haur horien euskarri emozionala ere izan behar duzu egoera horietan.» (IB)

Alegia, haurren jolas edo ekintzetan, presentzia eta beharrezko laguntza bakarrik eskaintzen ahalegintzea da bidelagunaren ardura, esku hartu gabe eta haurrari benetako protagonismoa helaraziz.

\subsection{Bizipen eta emozioei lekua}

Biziloreren asmo nagusietako bat berdintasunezko eta errespetuzko harremanak sustatzen dituen eskola komunitatea osatzea da.

«Harreman eredu sanoak sustatzen ahalegintzen gara, gatazka egoerei hitza jarri eta biktima-erasotzaile dikotomia gailenduta egoera kudeatzean.» (IB)

Eskolan helduek zein haurrek partekatzen dituzte euren egoera emozional eta sentipenak, eta hitzak jartzen zaizkie mementoei. Ekintza hori eskolako eremu guztietan eta edozein mementotan gerta daitekeen arren, batez ere harreman bizienak eta gatazka egoera gehienak mugimendu eremuan gertatzen dira (ikusi 18. irudia).

«Emozioak lantzen ditugu baina ez fitxa edota plangintza bidez; emozioaren momentuetan baizik. Bakoitzak bere emozioen ezagutza mailaren arabera, hitza jartzeko gaitasunaren arabera, egoera eta konfiantzaren arabera... identifikatu eta azaleratzen ditu emozioak. Guk emandako emozioak jasotzen ditugu; epaitu gabe eta mozten saiatu gabe. Gure presentzia eskainiz eta, behar izanez gero, hitza jartzen lagunduz. Helburua haurrek euren emozioen kudeaketan sakontzea da.» (MB) 


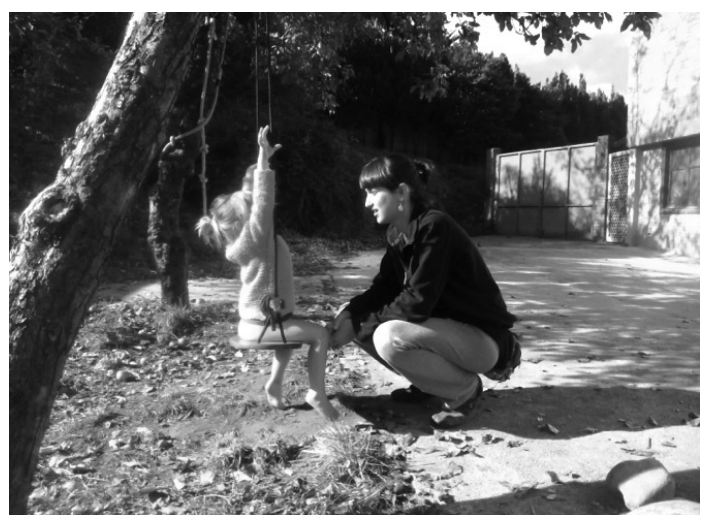

18. irudia

Bidelaguna haur batekin hizketan

Biziloren eskolaren egunerokotasunean eta hezkuntza harremanean bizipenei eta emozioe lekua egitea oinarri metodologiko garrantzitsuenetariko bat da.

\subsection{Eskola dinamikoa}

Eskolan hezkuntza proiektuari buruzko hausnarketak eta irakaspenak berrikusi eta eztabaidatzeko prozedurak bizi-bizi daude. Hilero egiten dituzte hausnarketa-bilerak eta haurtzaroa ulertzeko ezagupenei buruz hitz egiteko eta ideiak partekatzeko baliagarriak dira. Esate baterako, behar berrien eta egokitzapen mekanismo horien adibide dira ikerlana egin bitartean sortutako espazioaren antolaketa aldatzeko beharra eta ondorioz egindako aldaketak ${ }^{1}$.

«Ikusi dugu, egun eskolan diren ikasleen adin tartea kontuan hartuta, beharrezkoagoa zaiela gure begirada eta atentzioa, hain espazio zabala euren eskura jartzearen aldean. Horregatik, beharrezkoa ikusi dugu espazioa murriztea.» (IB)

Ildo beretik, eta haurtzaroa hobeto ulertzeko nahi horri jarraituz, dokumentazio lanak ere garrantzi berezia du. Bidelagunen behaketa-oharrez harago, eskolako momentu ugari bideo eta argazkietan jasotzen dira. Epe laburrean material horrekin ikus-entzunezko materiala sortzeko asmoa dute.

1 1. artikulu honetan espazioaren antolaketa zaharraren deskribapena jaso da baina aldaketa-prozesuaren hasierari tartea eskainiz. 


\subsection{Eskola eta familiaren arteko elkarlana}

Gurasoen ekimenez abian jarritako proiektua da Bizilore eta euren esfortzuari, gogoeta, auzolan eta asto-lanari (ikusi 19. irudia) esker ari dira eskola komunitate berri honen lehen urratsak finkatzen. Zentzu horretan, familiek eskolan duten parte-hartzea, zuzena izateaz gain, konpromiso maila handikoa da.

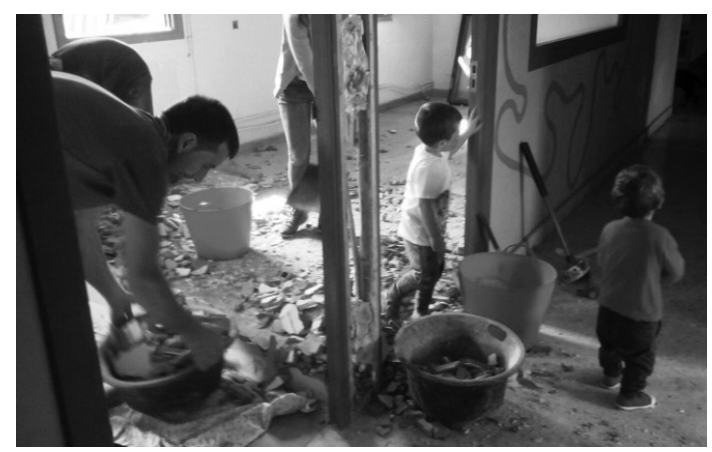

19. irudia

Gurasoak eta haurrak elkarrekin eraikina egokitzeko auzolanean

Hausnarketa-bilerak egiten dira hilero eta horietan familiek eskolari lotutako gai askoren inguruan gogoeta egiten dute (ikusi 20. irudia). Azken finean, Biziloren guztiak dira eskolaren funtsa edo bizkar-hezur eta guztien parte-hartzea ezinbestekoa da: familia, haurrak eta bidelagunak. Horregatik, guraso eta bidelagunen arteko konfiantza lantzen da, "haurrek ere ikusteko elkar zaintzen dutela eta ez dela harreman hotz bat»(IB).

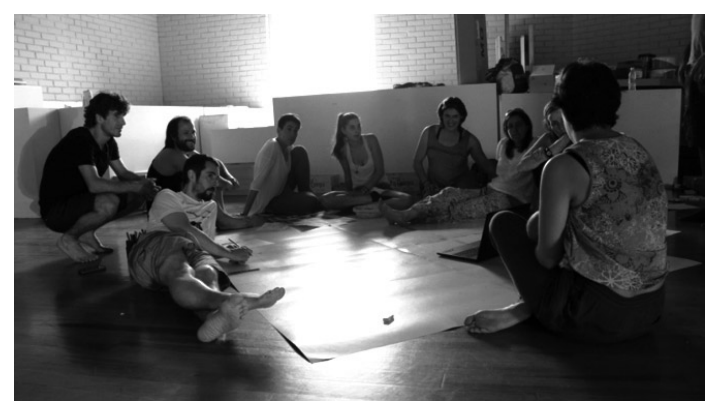

20. irudia

Familiak hausnarketa-bilera batean 


\subsection{Naturarekiko erlazioa}

Espazioen aukeraketan naturarekiko harremanari ematen zaion garrantzia handia da, Heinke Freire (2011) psikologoaren pedagogia berdea protagonista izateko. Kanpoko espazioari (ikusi «4.1.2.2. Kanpoko espazioa» atala) lehentasuna eskaintzen zaio, haurrek naturarekin duten harremana estua eta egunerokoa izan dadin.

Eskolako eraikinak eskaintzen dizkien aukerez gain, urtean zehar inguruko zenbait espazio naturaletara irteerak egiten dituzte (ikusi 23. eta 24. irudiak). Horietan, familien inplikazio maila agerikoa da eta beti daude laguntzeko prest.

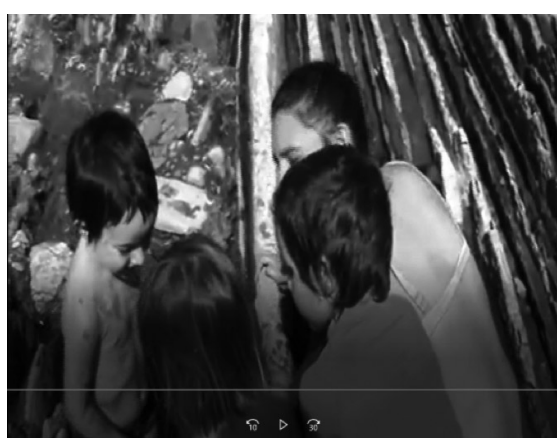

21. irudia

Haurrak eta bidelaguna Zumaiako Itzurun hondartzan

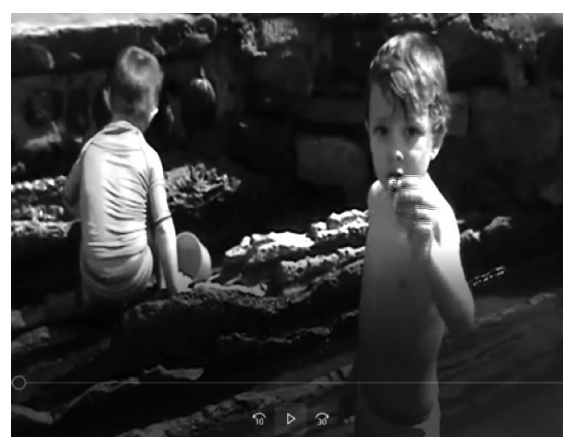

22. irudia

Haurrak arroken ingurunea arakatzen

Aurrera begira, gainera, naturarekiko harremana indartzeko ideia eta proiektu gehiago dituzte: baratza, oilategia, zubi tibetarra, eskuz abian jartzen den iturria edota tirolina. Horrekin batera, fruta- eta bestelako zuhaitz gehiago landatzeko asmoa dute. Helburua beti da haurrei zuzeneko ingurumen-esperientziak eta askatasun osoz kanpora irteteko aukera eskaintzea.

Izan ere, eskola oraindik espazioaren egokitze fasean dago eta epe motzean gainditu nahi dituzten segurtasun irizpideak tarteko, oraingoz, kanpo espaziorako irteera talde osoak elkarrekin egiten du. Horixe da, hain zuzen ere, hainbat ikasleren kexa: nahi baino denbora gutxiago pasatzen dutela kanpoko eremuan (LK). Horregatik, datozen urteetan kanpora irtetea eta bidelagunen presentzia erraztuko dituzte.

Eskola mundu naturalarekin zuzeneko harremanean eraikitzen jarraitu nahi dute; Jean Piaget (1987) haur-psikologo ezagunaren arabera, ezin zaio haurtzaroari kanpotik garapen moralik ezarri, beharrezkoa da aske eta autonomo izaten ikastea, hau da, esperimentatzeko eta, jakina, huts egiteko aukera izatea. 


\section{ONDORIOAK}

Ikerketa lan honen emaitzen atalean jasotakoaren arabera, baita eskoletan ere, bestela lan egiteko moduak praktikan jartzea posible da. Biziloreren esperientziak egiaztatzen du, hezkuntzan, haurrekin, bestelako harreman ereduak sustatu eta landu daitezkeela eta, baita, benetako ikaskuntza aktibo baten parametroetan, jarduera autonomoak eskaintzen duen plazera edozein haurren heziketan oso kontuan hartu beharreko elementua dela.

Piagetek (1987) aipatzen zuenez, ekintza da aktibitate intelektual ororen oinarria eta, horregatik, Biziloren ez dira haurraren ekintzak gidatzen, haurrak bere interes eta beharrei jarraituz ekintzak modu autonomoan garatzen ditu.

Ildo beretik, Hoyuelos (2010) adituak gogorarazten digu nola ekintza horiek aurrera eramateko garaian, bizitzako erritmoak, gizartearenak, familienak eta ikasleenak desberdinak diren. Haur bakoitzari, aurreratu gabe, behar duen denbora emateko ahalegina egiten dute Biziloren, hasi sarrerairteeren momentu delikatutik operazio konplexuen abstrakzioraino.

Aipatu bezala, behatutako eskolan haurrak bere garapenean aurrera egiteko hain beharrezkoa duen autonomiari erreparatzen zaio. Horretarako, eskolan, Haur Hezkuntzako bigarren etaparako giro egokiak prestatuak dituzte eta horrek haur bakoitzari, Maria Montessorik (1986) azpimarratzen zuen moduan, askatasunez mugitzeko aukera ematen dio.

Bestalde, ikerketa lanetik ondoriozta daiteke haurrak bere ingurunearekin harremanetan eta aire librean egindako jolasak funtsezkoak direla bere ongizaterako eta, ondorioz, ikaskuntza prozesurako. Horregatik, eraikin berrian kanpo espazio zabal eta eroso bat egokitu dute, haurrek kanpoan jolasteko eta zuzeneko ingurumen-esperientziak bizi ditzaten. Gainera, aurrera begira, kanpoko espazioaren protagonismoa handitzeko zenbait proiektu dituzte.

Baina horrekin batera, beharrezkoa da irakaslearen rolean aldaketa gertatzea. Wild pedagogoak (2007) aipatzen duenez, ikasleen ekintzak planifikatu eta definitu beharrean, helduaren ardura haurrak bere beharrei erantzuteko sortzen dituen elkarrekintzetan babesa eskaini eta elkarlanean aritzea izan beharko luke. Azken finean, eta Pikler Loczy (1984) Institutuarekin bat eginez, haur batek bere kabuz ikas dezakeen hori irakasten jardutea, alferrikakoa izatez gain, haurrarentzat kaltegarria ere badelako. Biziloreko bidelagunen esku-hartzeak delikatuak eta isilak dira, baina euren presentzia haurrekiko etengabea da. Haurrarekin daude une oro, haurraren ekintzak oztopatu, gidatu edota epaitu gabe.

Argi dago Bizilore eskola aktiboan haurra ez dela eskolan subjektu isolatu bat, bere inguruneko partaide bat baizik. Hezkuntza-ereduak bestela lan egiteko modu batzuk eskaintzen dizkie haurrei eta baita helduei ere. Irakaspenak eskaintzea baino, ikasketarako aukera desberdinak sortzen saiatzen dira. Horri esker, dituen beharren arabera eraikitzen du haurrak 
bere jarduera, askatasunez eta oztoporik, epaiketarik eta presiorik gabe. Horri guztiari, gainera, haurrek, «langile nekaezinak» direnez, modu espontaneoan, autonomoan eta euren ekintzen jabe izanik erantzuten diote.

Era berean, familien inplikazioa da eskola komunitate horren beste elementu garrantzitsua eta balio handikoa. Bizilore, gurasoek sortutako eskola bat da eta, ildo horretatik, eskolaren kudeaketan parte-hartze zuzena dute. Zentzu horretan, eta Dahlberg (2005) pedagogoarekin bat eginez, Bizilorek baieztatzen du posible dela erlazio eta aukera ugariko haurtzaro bati atea irekitzea, eta han familiek eta eskola erakundeek funtzio garrantzitsuak, osagarriak baina desberdinak izatea.

Horrekin batera, azpimarratzekoa da Biziloren asko zaintzen direla haurren, familien, pedagogoen eta gizartearen arteko erlazioak, guztiaren oinarria izateraino. Azken finean, eta Loris Malaguzzi pedagogoaren hitzetan, eskola bizirik dagoen erakunde bat da, osoa, helduek eta haur ugarik bizitza eta erlazioak partekatzen dituzten toki bat (Beresaluce, 2009; Edwars, Gandini, eta Forman, 1993).

\section{ETORKIZUNERAKO ERRONKAK}

Bizilore eskola aktiboaren oinarri pedagogiko eta metodologiak ezagutu ondoren, etorkizuneko erronka nagusia hezkuntzaren paradigmaren aldaketa da. Haurrekin modu egoki eta eraginkorrean lan egiteko eta haien beharrei zein ingurunearekin koherentzian aritzeko, eredu pedagogiko berriak ezagutu eta abian jartzeko beharra agerikoa da.

Eskola jendartean azken urteotan eman diren aldaketetara egokitzea funtsezkoa da; egun ez dio jendarteak dituen beharrei erantzuten, eta haur asko eta asko, eskolan, motibazioa bilatu ezinean dabiltza. Horri aurre egiteko, haurrari entzun eta hitza emango dioten eskola eredu berriak behar dira: norbere hazkuntza prozesu bakar eta pertsonal askean oinarritzen diren eskolak, epaiketetatik, balorazioetatik eta interpretazioetatik urrun daudenak. Entzutea haurraren kultura ulertzeko artea da (Berasaluce, 2009) eta dituen behar eta interesei erreparatzeko bidea.

Bada garaia ikasketa-prozesua bera balioesteko eta ikasketarako aukera desberdinak sortzeko, Italiako Reggio Emilia eskoletan egiten ari diren antzera. Haurrei esperientzia ahaztezinak eskaini behar zaizkio, betiere ongizatea lehenetsiz. Umea ondo baldin badago, berezko ahalmenak garatuko ditu, eta beste guztia, ikastea, adibidez, horren ondorio izango da (Barandiaran eta Larrea, 2016). Bizitza eta emozioak dira ikasketa-prozesuaren erdigune.

Ildo horretatik, Azkoitiko Bizilore eskola aktiboan oinarri sendoak eraikitzen ari dira, haurrei esperientzia zirraragarri horiek eta euren ikaskuntza modu aktiboan eraikitzeko aukera eskainiz. Oraindik eskola komunitate hori bere lehen urratsak egiten ari bada ere, argi ikusi da lehentasuna 
umearen autonomia, askatasuna eta ongizatea dela. Gainera, prozesuari buruzko hausnarketa etengabekoa da eta familiek proiektuan inplikazioa aktiboa dute.

Bidea ez da erraza izan. Nolanahi ere, Bizilore bestelako eskola eredu bat posible denaren ispilua eraikitzen ari da. Erronka handia da hezkuntza-ereduak aldatzea eta luzea eskolaren kultura berri bat eraikitzeko bidea, baina helburuak merezi du: umeen ongizateak.

Jasotze-data: 2017/09/29

Onartze-data: 2018/03/06

\begin{abstract}
We are witnessing in the present a progressive emergence of new and stronger voices and experiences supporting a new model of school where the students won't just learn what they are taught by their teacher, or where everyone won't be oriented to the achievement of some established goals. The present research analyzes the case study of «Bizilore eskola» in Azkoitia (Gipuzkoa), focusing on the relevance this new model of school we mentioned before entails. The research has been carried out considering and analyzing the data obtained from a participative fieldwork where several issues and situations with parents, teachers and paperwork have been tackled. The compiled data has been later contextualized considering the contribution of some relevant authors and theories. Among the conclusions, we can identify some pedagogical basis of active schools oriented to the welfare of the kids. We also consider the possibility of putting into practice the aforementioned basis.
\end{abstract}

Keywords: kids' welfare, active school, education ethnography, paperwork, Early Childhood Education.

Hoy en día, y aunque el proceso sea lento, emergen, cada vez con más fuerza, voces y experiencias a favor de un modelo de escuela en el que, entre otras cuestiones, el alumnado no aprende solo lo que el profesorado le enseña, ni todos los participantes tienen por qué conseguir los mismos objetivos. Este artículo nos lleva a reflexionar en torno a este otro modelo de escuela, a través de la investigación etnográfica de la experiencia que están viviendo en la escuela Bizilore de Azkoitia. La investigación se desarrolla a partir de la observación participante de la vida cotidiana, de las conversaciones con el profesorado, de madres y padres, y de la revisión de la documentación. 
Todo ello se pone en discusión con las aportaciones de diferentes autores de referencia y con otras experiencias. Entre las conclusiones, se identifican las bases pedagógicas de una escuela activa centrada en el bienestar de la niña y el niño y se identifican las posibilidades de su puesta en práctica.

Palabras clave: bienestar del niño y la niña, escuela activa, etnografía educativa, documentación, Educación Infantil.

De nos jours, et bien que le processus soit lent, les voix et les expériences émergent chaque fois avec plus de force en faveur d'un modèle de l'école dans lequel, entre d'autres questions, les élèves n'apprennent pas seulement ce que le professorat l'enseigne, ni dans lequel tous les participants doivent réussir les mêmes objectifs. Cet article nous amène à réfléchir autour une autre modèle d'école, à travers la recherche ethnographie de l'expérience qu'on peut être vécu dans l'école Bizilore de Azkoitia. La recherche est développée à partir de l'observation participante sur la vie quotidienne de celle-ci, des conversations avec les enseignants, avec les mères et les pères et de la révision de la documentation. Tout cela est mis en discussion avec les contributions des différents auteurs de référence et avec d'autres expériences. Entre les conclusions, on identifie les bases pédagogiques d'une école active pointée sur le bien-être des petites enfants et sont identifiées les possibilités de sa mise en pratique.

Mots-clé: bien-être des enfants, école active, éducation, documentation, Education de la Petite Enfance.

\section{ERREFERENTZIA BIBLIOGRAFIKOAK}

Álvarez-Uria, A., Tresserras, A., Zelaieta-Anta, E., eta Vizcarra, M. T. (2015). La obra teatral «Kubik» y su valor pedagógico-artístico. Enseñanza \& Teaching: Revista Interuniversitaria de Didáctica, 1(33), 143-161. <http://revistas.usal. es/ revistas_trabajo/index.php/02125374/article/view/et2015331143161>-tik berreskuratua.

Aucouturier, B. (2012). L'enfant Terrible. Bartzelona: Graó.

Barandiaran A. eta Larrea I. (2016). Ebaluazioa Haur Hezkuntzan, paradigma aldaketa. Hik Hasi, 29 (monografikoa).

Beresaluce, R. (2009). Las escuelas reggianas como modelo de calidad en la etapa de educación infantil. AulaAbierta, 37(2), 123-130.

Casanova, E.M. (1989). El proceso educativo según Carl R Rogers: la igualdad y formación de la persona. Revista Interuniversitaria de Formación del Profesorado, 6, 599-603. 
Dahlberg, G. (2005). Más allá de la calidad en educación infantil. Bartzelona: Paidós.

Dale, E. (1964). Métodos de Enseñanza Audiovisual. Mexiko: Reverté.

Decroly, O. (1987). Experiencias educativas e innovadoras. Madril: Passat.

Delval, J. (1996). ¿Cómo se construye el conocimiento? Universidad Autónoma de Madrid. http://docplayer.es/145587-Como-se-construye-el-conocimiento. html-tik berreskuratua.

Edwards, C., Gandini, L., eta Forman, G. (1993). The hundred languages of children: the Reggio Emilia Approach to early childhood education. Norwood, NJ: Ablex. ED 355034.

Fisher, J. (2008). Starting from the Child: Teaching and Learning from 4-8. Maidenhead: Open UniversityPress.

Freire, H (2011). Educar en verde. Ideas para acercar a niños y niñas a la naturaleza. Bartzelona: Graó.

Herrán, E. (2013). La Educación Pikler-Lóczy: Cuando educar empieza por cuidar. RELAdEI. Revista Latinoamericana de Educación Infantil, 2(3), 37-56.

Hoyuelos, A (2007). Documentación como narración y argumentación. Aula Infantil, 39, 5-9.

Hoyuelos, A (2010). Los tiempos de la infancia, Bartzelona: Universidad Autónoma de Barcelona.

Hoyuelos, A. (2004): La ética en el pensamiento y obra pedagógica de Loris Malaguzzi. Bartzelona: Octaedro Rosa Sensat.

Juaristi, P. (2003). Gizarte ikerketarako teknikak. Leioa: Euskal Herriko Unibertsitatea.

Laguía, M. J. (2008). Rincones de actividad en la escuela infantil (0 a 6 años). Bartzelona: Graó.

Latorre, A. (2003). La investigación-acción. Conocer y cambiar la práctica educativa. Bartzelona: Graó.

Montessori, M (1986). La mente absorbente del niño. Mexiko: Editorial Diana.

Olvera, A. (2009). Pedagogía del siglo XXI. El éxito es tu historia. Mexiko: Cudec.

Paniagua, G., eta Palacios, J. (2005). Educación Infantil: Respuesta Educativa a la Diversidad. Madril: Alianza.

Pareja, J. A. (2011). Modelos globalizadores y técnicas didácticas interdisciplinares. Dpto. Didáctica y Organización Escolar: Universidad de Granada, 1-23. http://www.ugr.es/ fjjrios/pce/media/7ModelosGlobalizadoresTecnicas Interdisciplinares.pdf-tik berreskuratua.

Pastor, J.L. (2002). Fundamentación conceptual para una intervención psicomotriz en Educación Física. Bartzelona: Inde Publicaciones.

Piaget, J. (1987). El criterio moral en el niño. Bartzelona: Fontanella.

Pikler, E. (1984). Moverse en libertad: desarrollo de la motricidad global. Madril: Nancea.

Ruiz de Velasco, A. y Abad, J. (2011). El juego simbólico. Bartzelona: Graó.

Tardos, A. (1992). Autonomía y/o dependencia. Educar de 0 a 6. Revista Infancia, $15,4-9$.

Taylor, S.J. eta Bogdan, R. (1992). Introducción a los métodos cualitativos de investigación. Buenos Aires: Paidos.

Traveset, M. (2007). La Pedagogía Sistémica: Fundamentos y práctica. Bartzelona: Graó. UNESCO (2004). Educación para todos. El imperativo de la ca- 
lidad. http://www.unesco.org/education/gmr_download/es_summary.pdf -tik berreskuratua.

Vygotski, L. S. (1979) El desarrollo de los procesos psicológicos superiores. Buenos Aires: Grijalbo

Wallon, H. (1942). De l'acte á la pensé. Essai de psychologie comparée. Paris: Flammarion. [Trad. Cast. Del acto al pensamiento. Ensayo de psicología comparada. Buenos Aires: Psiqué, 1974].

Wild, R. (2007). Aprender a vivir con niños. Ser para educar. Bartzelona: Herder. Zabalza, M.A. (1996). La calidad en la Educación Infantil. Madril: Narcea. 